\title{
Dinamika Konflik Internal Pada Partai Persatuan Pembangunan Pasca Pemilu Tahun 2014
}

\author{
1* Qurnia Indah Permata Sari
}

${ }^{1}$ Mahasiswa Doktor Program Studi Sosiologi, Universitas Brawijaya, Malang, Indonesia

\begin{abstract}
Partai Persatuan Pembangunan (PPP) merupakan fusi dari keempat Partai Islam yang ikut serta pada Pemilu 1971 untuk menyederhanakan sistem kepartaian menjelang Pemilu 1977. Menjelang Pemilu tahun 2014 partai ini dilanda konflik internal yang berlarutlarut hingga kini. Konflik internal yang seharusnya bisa diselesaikan oleh mekanisme internal partai gagal, hingga masuknya campur tangan pemerintah dengan terbitnya SK Menkumham dan pengangkatan Menteri Agama dari kubu PPP Romahurmuzy yaitu Lukman Hakim Syarifuddin. Studi kualitatif ini bertujuan untuk menganalisis dinamika konflik Partai Persatuan Pembangunan, campur tangan pemerintah dalam konflik internal PPP serta dampak konflik internal bagi DPW dan DPC di daerah.
\end{abstract}

Keywords: PPP; Pemilu 2014; Konflik Politik

\section{Latar belakang}

Partai Persatuan Pembangunan (PPP) berdiri pada tanggal 5 Januari 1973 berasaskan Islam. PPP merupakan fusi dari keempat Partai Islam yang ikut serta pada Pemilu 1971. Partai-partai yang difusi tersebut adalah Partai NU, Parmusi, PSII dan Perti. Tujuan dari fusi ini adalah penyederhanaan sistem kepartaian menjelang Pemilu 1977 (Rozabi, 2012).

\section{Kelahiran Partai Persatuan} Pembangunan merupakan penyelamat aspirasi umat Islam dan kesadaran tokohtokoh umat Islam dan pimpinan partai untuk bersatu dalam membina masyarakat agar lebih meningkatkan

\footnotetext{
* Corresponding author: Qurnia Indah Permata Sari qurniaindahpermatasari@gmail.com

Published online at http://islamicinsights.ub.ac.id/

Copyright (C) 2020 PSP2M UB Publishing. All Rights Reserved
}

keimanan dan ketakwaan kepada Allah SWT melalui perjuangan partai politik (Tim Litbang Kompas, 2004).

Sebagai jalan untuk mencapai tujuan yang mereka inginkan para pemimpin dan aktivis Islam politik bergantung kepada, Pertama, politik nonintegratif atau partisan, Kedua, parlemen sebagai satu-satunya lapangan bermain dan arena perjuangan Parlemen sebagai satu-satunya arena bagi artikulasi dan realisasi tujuan-tujuan sosial-keagamaan dan politik islam. PPP mengambil jalan parlemen sebagai arena perjuangan.

Eksistensi Partai Persatuan Pembangunan (PPP) seringkali mengalami pasang surut, hal ini dilihat dari hasil perolehan suara yang fluktuatif dari pemilu ke pemilu, karena dipengaruhi arah kebijakan yang diambil oleh partai maupun konflik internal yang 
terjadi pada tubuh partai ini sendiri. Asas Partai ini pun sempat berubah tercermin pada Muktamar I tahun 1984, yang semula berasaskan Islam menjadi berasaskan Pancasila. Sesuai dengan Pasal 2 UU No. 3 tahun 1985 yang mensyaratkan bahwa harus berasas tunggal Pancasila (Fadjar, 2008), kemudian pada Muktamar IV di Jakarta 29 November - 2 Desember 1998 yang menghasilkan amanat bahwa PPP harus kembali berasaskan Islam. PPP berdasarkan jenisnya termasuk jenis Partai Proto yang dibentuk berdasarkan pengelompokkan ideologis masyarakat yang menjadi konstituennya. Basis pendukung PPP meliputi wilayah: Jakarta, Jawa Timur, Jawa Tengah, dan Jawa Barat (Hamad, 2014).

Konflik internal yang terjadi sebelum pemilihan umum 2014 ini pernah terjadi sebelumnya, yaitu sebelum pemilihan umum tahun 1987. PPP saat itu juga dilanda oleh konflik internal antara kelompok NU dan MI. Saat itu kelompok NU bersikeras melakukan walk out pada saat pembahasan Rantap tentang GBHN (aliran kepercayaan) di komisi A dan Rantap tentang P4 di komisi B. Sedangkan dari unsur MI, SI dan Perti ingin tetap mengikuti pemungutan suara. Konflik antara NU dan MI dalam berbagai ranah politik parlemen ketika itu semakin mengeras. Dampak konflik internal PPP tersebut adalah mundurnya NU dari keanggotaan PPP pada tahun 1987 dan merosotnya suara PPP pada Pemilu 1992. Pada Pemilu tahun 1987 suara PPP sebesar 20.871.880 merosot drastis suaranya 13.701.428 (Hamdi, 2013).

Konflik internal PPP terus berlangsung hingga menjelang Pemilu 2019, karena perbedaan arah dukungan antara kubu Romahurmuzy dan Kubu Humprey Djemat. Politik belah bambu yang dilakukan oleh Rezim Jokowi terhadap PPP, semakin memperkeruh persoalan internal PPP, yang mestinya bisa diselesaikan pada ranah internal PPP sendiri. Politik belah bambu bukan saja mengakibatkan semakin tingginya ketidakpercayaan masyarakat pada PPP, namun juga merusak Islam politik pada panggung politik Indonesia (Warijo, 2015).

Studi ini menemukan bahwa terdapat indikator campur tangan pemerintah dalam kasus internal PPP, Pertama, pengangkatan Menteri Agama dari kubu PPP Romahurmuzy yaitu Lukman Hakim Syarifuddin, dengan harapan bahwa PPP diparlemen dapat mendukung pemerintahan Jokowi. Kubu Romahurmuzy kemudian menolak nama-nama komisi dan alat kelengkapan dewan yang diajukan oleh kubu Surya Dharma Ali, Kedua, Presiden Jokowi menggunakan kekuasaan kabinetnya, yaitu melalui Menkumham mengeluarkan surat yang menetapkan kubu Romahurmuzy adalah kubu yang legal dalam kepengurusan PPP (Warijo, 2015).

Menurut Fisher penyebab konflik terdiri atas beberapa hal, Pertama, terjadinya polarisasi, ketidakpercayaan dan permusuhan antar kelompok yang berbeda dalam satu komunitas, Kedua, disebabkan posisi yang diadopsi kelompok bertentangan semata, Ketiga, kebutuhan manusia yang tidak tercukupi (fisik, psikologis dan sosial), Keempat, identitas yang terancam, Kelima, miskomunikasi antar budaya karena gaya yang berbeda, Kelima, transformasi konflik disebabkan karena ketidaksetaraan dan ketidakadilan. Dari beberapa faktor penyebab konflik yang disebutkan oleh Fisher, Dkk yang paling sesuai adalah sebagai berikut, Pertama, terjadinya polarisasi, ketidakpercayaan dan permusuhan antar kelompok yang 
berbeda dalam satu komunitas dan Kedua, disebabkan posisi yang diadopsi kelompok bertentangan semata. Penelitian ini berusaha memperluas Teori Faktor Penyebab Konflik yang dikemukakan oleh Fisher dengan menambahkan sebuah poin bahwa terdapat faktor eksternal yang berasal dari luar kelompok yang berkonflik dibalik konflik yang terjadi di Partai Persatuan Pembangunan sehingga konflik tersebut, tidak mampu terselesaikan hingga saat ini yaitu faktor campur tangan pemerintah, misalkan keluarnya SK Kemenkumham yang mengesahkan salah satu pihak dan tidak mempertimbangkan kekecewaan pada pihak lain (Academic Gap). Sedangkan Empirical Gap seharusnya konflik PPP mampu diselesaikan oleh pihak pengadilan, namun nyatanya konflik PPP terus berlanjut hingga kini. Meskipun telah terbit Putusan Mahkamah Agung dengan mengesahkan Kubu Romahurmuzy, namun dualisme DPP Pusat masih terus berlangsung dengan ditunjukkannya arah kebijakan partai yang berlawan. Masing-masing pihak berusaha menunjukkan dominasinya terhadap partai dengan memberikan pernyataan-pertanyaan politik yang dapat menyebabkan terpecahnya suara partai arus bawah dan kebingungan konstituen.

Terdapat beberapa literatur yang sebelumnya mengkaji tentang konflik PPP diantaranya sebagai berikut, Pertama, kronologi konflik internal (Arawan, 2018); Kedua, dampak konflik internal bagi elit lokal (Gunawan, 2017). Penelitian ini bertujuan untuk melengkapi penelitian sebelumnya dengan memaparkan Dinamika konflik internal PPP, campur tangan pemerintah dalam konflik internal PPP serta dampak konflik internal bagi DPW dan DPC di daerah.

\section{Literatur Review}

\subsection{Partai Politik}

Menurut Ridho Alhamdi, Partai Politik Islam adalah sebuah organisasi memperjuangkan nilai-nilai islam dalam konteks yang berbeda melalui penguasaan struktur kelembagaan pemerintah baik pada level legislatif maupun eksekutif. Proses mendapatkan kekuasaan diperoleh dengan keikutsertaan dalam pemilu serta melakukan kampanye dengan menjual isu dan program-program yang tidak lepas dari nilai-nilai ideologis islam (Al-Hamdi, 2013).

Partai Politik Islam memiliki dua konotasi, Pertama, ideologi sebuah organisasi, yaitu merujuk kepada partai politik yang menjadikan islam sebagai dasar ideologinya. Ideologi organisatoris dianggap penting karena merupakan tujuan dan orientasi. Ideologi menjadi pembeda antara satu partai dengan partai yang lain. Kedua, basis sosio-kultural, partai politik sebagai sarana bagi masyarakat untuk menyalurkan aspirasi politiknya. Sehingga, identitas dari sebuah partai tidak hanya pada bentuk organisasinya, namun lebih kepada basis sosio-kultural kelompok masyarakat yang diwakilinya (Al-Hamdi, 2013). Menurut Romli membagi partai yang berasas islam ke dalam tiga kategori, Pertama, Partai Islam yang berasas Islam, Kedua, Partai Islam yang berasaskan Islam dan Pancasila, Ketiga, Partai Islam yang berasaskan Pancasila tetapi berbasis massa mayoritas dari kalangan muslim (Al-Hamdi, 2013).

\subsection{Dinamika Konflik}

Konflik merupakan sebuah gejala sosial yang tidak bisa dilepaskan pada setiap kehidupan masyarakat dari waktu ke waktu. Konflik merupakan sebuah produk hasil dari hubungan sosial. 
Konflik berkembang luas di dalam masyarakat, karena konflik tersebut tidak mempunyai titik temu dalam penyelesaian masalah. Menurut Albert F. Eldridge, konflik didefinisikan sebagai suatu bentuk perbedaan ide, pendapat, paham dan kepentingan diantara dua pihak atau lebih (Haris, 1988).

Konflik dapat dibedakan menjadi dua jenis, yaitu konflik lisan atau konflik non-fisik dan konflik fisik. Konflik lisan atau konflik non fisik berbentuk debat, polemik, perbedaan pendapat yang dapat disebut konflik. Konflik lisan dapat dikategorikan sebagai konflik karena terlihat adanya pertentangan di dalamnya meskipun tindakan kekerasan melibatkan benda-benda fisik belum terjadi. Bila konflik tersebut tidak dapat diselesaikan, konflik tersebut dapat berkembang menjadi konflik fisik. Konflik fisik dapat meningkat menjadi konflik fisik seperti menggunakan benda-benda tumpul maupun benda tajam. Mereka berusaha untuk mempertahankan pendapat masing-masing untuk mengelahkan (bahkan membunuh) pihak lain yang menjadi musuh (Rauf, 2000). Konflik fisik misalnya seperti, pemberontakan, revolusi dan kerusuhan politik (Gurr, 1980).

Menurut Margaret M. Poloma, konflik berfungsi menegakkan dan mempertahankan identitas dan batasbatas kelompok sosial dan masyarakat (Poloma, 1994). Sedangkan, Politik menurut David Apter berkaitan adalah perebutan kuasa, takhta dan kekayaan untuk kepentingan diri sendiri (Apter, 1985).

Menurut Ramlan Surbakti, konflik politik adalah perbedaan, persaingan dan pertentangan diantara sejumlah individu kelompok ataupun organisasi dalam upaya mendapatkan dan mempertahankan sumber-sumber dari keputusan yang dibuat dan dilaksanakan oleh pemerintah (Surbakti, 2010).

Roger, W. Cobb mengungkapkan tiga dimensi penting dalam konflik politik, yaitu Pertama, luas konflik merunjuk pada jumlah perorangan atau kelompok yang terlibat didalam konflik, serta menunjuk pada skala konflik yang terjadi, Kedua, Intensitas Konflik merujuk pada sempit-luasnya komitmen sosial yang bisa terbangun akibat sebuah konflik. Konflik yang intensitasnya tinggi adalah konflik yang bisa membangun komitmen sosial yang luas, sehingga luas konflik pun mengembang, Ketiga, Ketampakan konflik adalah tingkatan kesadaran dan pengetahuan masyarakat diluar pihak-pihak yang berkonflik, tentang peristiwa konflik yang terjadi. Sebuah konflik dikatakan mempunyai ketampakan yang tinggi manakala peristiwa konflik itu disadari dan diketahui detail keberadaannya oleh masyarakat secara luas. Sebaliknya, sebuah konflik memiliki ketampakan rendah manakala konflik itu terselimuti oleh berbagai hal sehingga tingkat kesadaran dan pengetahuan masyarakat luas terhadap konflik itu sangat terbatas, Keempat, Pemberian sanksi pada aktor yang terlibat konflik. Pemberian sanksi tersebut terkait dengan kerangka dan keadilan hukum (Fatah, 1994).

Menrut Fisher penyebab konflik terdiri atas beberapa hal, Pertama, terjadinya polarisasi, ketidakpercayaan dan permusuhan antar kelompok yang berbeda dalam satu komunitas, Kedua, disebabkan posisi yang diadopsi kelompok bertentangan semata, Ketiga, kebutuhan manusia yang tidak tercukupi (fisik, psikologis dan sosial), Keempat, identitas yang terancam, Kelima, miskomunikasi antar budaya karena gaya yang berbeda, Kelima, transformasi 
konflik disebabkan karena ketidaksetaraan dan ketidakadilan. Dari beberapa faktor penyebab konflik yang disebutkan oleh Fisher, Dkk yang paling sesuai adalah sebagai berikut, Pertama, terjadinya polarisasi, ketidakpercayaan dan permusuhan antar kelompok yang berbeda dalam satu komunitas dan Kedua, disebabkan posisi yang diadopsi kelompok bertentangan semata. Penelitian ini berusaha memperluas Teori Faktor Penyebab Konflik yang dikemukakan oleh Fisher dengan menambahkan sebuah poin bahwa terdapat faktor eksternal yang berasal dari luar kelompok yang berkonflik dibalik konflik yang terjadi di Partai Persatuan Pembangunan sehingga konflik tersebut, tidak smampu terselesaikan hingga saat ini yaitu faktor campur tangan pemerintah (Academic Gap).

Terdapat beberapa tahapan dinamika konflik dan eskalasi konflik yang dapat dilihat, tahap-tahap tersebut sebagai berikut, Pertama, Latent Tension, konflik masih dalam bentuk kesalahpahaman antara satu dan lainnya, tetapi antara pihak yang bertentangan belum terlibat konflik, Kedua, Nescent Conflict, konflik mulai tampak dalam bentuk pertentangan meskipun belum menyertakan ungkapan-ungkapan ideologis dan pemetaan terhadap pihak lawan secara terorganisir, Ketiga, Intentensifed Conflict, konflik berkembang dalam bentuk yang terbuka disertai radikalisasi gerakan diantara pihak yang saling bertentangan dan masuknya pihak ketiga dalam arena konflik.

\subsection{Resolusi Konflik}

Menurut Robinson dan Clifford, Resolusi konflik merupakan tindakan konstruktif yang direncanakan, diorganisasikan, digerakkan dan dievaluasi secara teratur dengan menggunakan semua usaha untuk mengakhiri konflik. Resolusi Konflik harus dilakukan sejak konflik pertama kali tumbuh, karena apabila tidak dikelola konflik dapat menimbulkan tindakantindakan kekerasan (Liwori, 2018).

Resolusi Konflik bertujuan menangani sebab-sebab konflik dan berusaha membangun hubungan baru yang relatif dapat bertahan lama diantara kelompok-kelompok yang sedang bermusuhan (Liwori, 2018). Terdapat beberapa bentuk penyelesaian konflik yaitu, Pertama, menghindari, Kedua, pemecahan masalah secara informal, Keempat, bernegosiasi, Kelima, munculnya pihak ketiga yang melakukan mediasi, Keenam, kemunculan pihak yang lain yang memberi bentuk penyelesaian, Ketujuh, intervensi pihak berwenanang dalam memberi kepastian hukum, Kedelapan, intervensi melalui musyawarah dan lembaga perwakilan rakyat dan penanganan oleh pihak yang memiliki kekuatan legal (Susan, 2017).

Sedangkan Menurut Wahyudi terdapat beberapa model manajemen konflik, sebagai berikut, Pertama, Model Integratif dilakukan dengan cara melakukan negosiasi untuk mencari kesepakatan bersama terhadap konflik yang sedang terjadi. Hasil yang diharapkan dari model penyelesaian konflik integratif adalah sebuah kesepakatan, dimana keputusan yang diambil dapat sama-sama menguntungkan kedua belah pihak yang ditunjukkan pada kondisi menangmenang. Penyelesaian konflik melalui model integratif dilakukan dengan cara konsesus, konfrontasi dan penggunaan tujuan (kepentingan) yang lebih tinggi, Kedua, Model Stimulasi Konflik. Model Stimulasi Konflik adalah dengan mendorong konflik yang sedang terjadi dan membahasnya secara bersama-sama, secara sengaja dan direncanakan agar 
menemukan solusi yang lebih baik. Model stimulasi manajemen konflik, dilakukan dengan cara sebagai berikut, Pertama, melalui musyawarah, Kedua, menghadirkan orang ketiga, Ketiga, konfrontasi, Keempat, tawar-menawar, Ketiga, kompromi. Dengan cara-cara tersebut stimulus dapat menyelsaikan konflik. Ketiga, Model Distributif, kedua belah pihak dihadapkan untuk menyelesaikan konflik, Resolusi konflik yang diharapkan adalah menang-kalah. Pilihan yang ditawarkan cenderung memihak salah satu pihak, Keempat, Model Pengurangan Konflik, terdapat dua cara dalam mengurangi konflik, yaitu Pertama, mendinginkan temperatur perselisihan, Kedua, menyatukan kelompok-kelompok yang berselisih dan memungkinkan pihak yang berselisih agar berinteraksi satu sama lain. Diharapkan melalui kegiatan bersama kedua belah pihak dapat menurunkan egonya dan memilih fokus pada kegiatankegiatan yang menjadi tanggungjawab bersama. Kelima, Model Penangan Konflik yang Inovatif yaitu mengelola hubungan negatif yaitu hubungan yang tidak sehat. Mengelola hubungan negatif ini dilakukan dengan cara pencegahan dan penghindaran konflik yang lebih besar (Puspita, 2018).

\section{Hasil dan Pembahasan}

\subsection{Dinamika Konflik Internal PPP}

Dinamika konflik politik yang terjadi ini seperti dikemukakan oleh Roger, Pertama, luas konflik yang terjadi, konflik internal PPP sebenarnya hanya terjadi diinternal DPP dalam PPP, konflik tersebut terjadi karena kesalahan yang dilakukan oleh Surya Dharma Ali sebagai Ketua DPP dan Djan Farid selaku dan Wakil Ketua Umum Djan Faridz menghadiri pada kampanye akbar Partai Gerindra di Stadion Gelora Bung Karno di Senayan pada tanggal 23 Maret
2014. Padahal secara resmi PPP belum mengumumkan secara resmi calon presiden yang akan diusung dan sedang fokus dalam pemilihan legislatif.

Keputusan Suryadharma Ali dan Djan Farid untuk menghadiri kampanye akbar Partai Gerindra dinilai merupakan keputusan sepihak oleh para elit PPP, karena dalam Mukernas II PPP di Bandung, PPP memutuskan untuk menjalin komunikasi politik dengan delapan capres (Irfan, 2014) dan capres yang didukung oleh PPP akan diumumkan setelah Pemilihan Legislatif 9 April 2014. DPP PPP kemudian menggelar rapat antara Suryadharma dengan kelompok yang tidak setuju dengan keputusan dukungannya ke Prabowo dan menghasilkan islah. Kedua, Ketampakan konflik, konflik diketahui publik semenjak Suryadharma memecat pihak-pihak yang bersebrangan dengannya diantaranya, Wakil Ketua Umum Suharso Manoarfa serta beberapa ketua DPW PPP yang dianggap akan memakzulkan dirinya (Irfan, 2014).

Ketiga, Intensitas Konflik. Semula konflik PPP hanya dibahas didalam internal partai PPP, desas desus tersebut menyebar hingga ke Dewan Perwakilan Wilayah. Sebanyak 27 Dewan Pimpinan Wilayah (DPW) mendesak pengurus pusat untuk memberi sanksi kepada Surya Dharma Ali dan Djan Farid lantaran dianggap menyalahi AD/ART partai sebagaimana ketetapan Muktamar VI Partai Persatuan Pembangunan No. 03/TAP/Muktamar/VI/PPP/1/2007 tanggal 01 Februari 2007 Bab V tentang Kedaulatan partai yang berada sepenuhnya di tangan anggota dengan cara dilaksanakannya Muktamar.

Pengurus harian DPP PPP menggelar rapat internal pada tanggal 18 April juga mengelar rapat yang 
menghasilkan sembilan putusan, salah satunya diberikan surat peringatan pertama. Pada saat yang sama Ketua Umum PPP Suryadharma Ali menyatakan dukungan kepada Prabowo sebagai calon presiden (bbc.com, 2014).

Keempat, Pemberian sanksi pada aktor yang terlibat konflik. Pada tanggal 19 April, DPP PPP menggelar Rapimnas untuk mengevaluasi hasil Pemilihan Legislatif dan mengevaluasi konflik internal partai. Suryadharma Ali serta para pendukungnya tidak menghadiri rapat tersebut sehingga rapat dipimpin oleh Romahurmuzy dan Wakil Ketua Umum Emron Pangkapi. Berdasarkan rapat tersebut sesuai pasal 12 ayat 1 Anggaran Rumah Tangga PPP hingga pelaksanaan Muktamar. Beberapa kader yang sebelumnya dipecat oleh Suryadharma juga dipulihkan kembali. Namun, Rapimnas tersebut menurut Suryadharma tidak sah karena dirinya tidak hadir Surya bahkan mengancam akan memberikan sanksi pada kader yang hadir dalam Rapimnas.

Pada Mukernas II yang di gelar di Bogor pada 24 April lalu, Suryadharma sempat meminta maaf dan mengakui kesalahannya. kedua kubu yakni kubu Suryadharma dan kubu Romahurmuzy akhirnya menyepakati islah. Namun, Pada tanggal 2 Mei, Suryadharma Ali menyodorkan draft persetujuan dukungan untuk Capres Partai Gerindra pada rapat di Hotel JS Luwansa. Hal tersebut dinilai melanggar kesepakatan islah yang dipimipin oleh $\mathrm{KH}$ Maemun Zubair selaku Ketua Majelis Syariah DPP PPP pada tanggal 23 April, dimana semua pihak yang terlibat perseteruan kembali ke posisi nol (Irfan, 2014).

\section{Konflik menjadi Intentensifed} Conflict, karena berkembang dalam bentuk yang terbuka disertai gerakan diantara pihak yang saling bertentangan dan masuknya pihak ketiga dalam arena konflik. Pada 22 Mei 2014, Suryadharma Ali ditetapkan sebagai tersangka oleh KPK dalam kasus korupsi Dana Haji sebesar Rp. 230 miliar sebagai transaksi yang mencurigakan (Pamungkas, 2019). Djan Farid pun ditetapkan sebagai Ketua Umum PPP, namun banyak dari kader PPP sendiri menolak Djan Farid karena juga dianggap menyalahi AD/ART partai sebagaimana ketetapan Muktamar VI Partai Persatuan Pembangunan No. 03/TAP/Muktamar/VI/PPP/1/2007 tanggal 01 Februari 2007 Bab V tentang Kedaulatan partai.

Perpecahan internal dalam tubuh PPP terus berlanjut. Kubu Romahurmuziy menggelar Muktamar di Surabaya pada tanggal 15-18 Oktober yang diputuskan berdasarkan Rapat Pengurus Harian ke-18 tanggal 9 September 2014. Dalam Muktamar tersebut Romahurmuzy ditetapkan sebagai Ketua Umum dan arah Dukungan PPP pasca Pilpres Tahun 2019 adalah mendukung Joko Widodo dan Jusuf Kalla. Muktamar tersebut dihadiri oleh 26 dari 33 DPW PPP se Indonesia (Setyadi, 2020).

KH. Maemun Zubair selaku Ketua Majelis Syariah PPP tidak mengakui hasil muktamar PPP Surabaya yang menetapkan Romahurmuzy sebagai ketua umum PPP. Hal tersebut karena muktamar yang digelar di Surabaya tersebut dihelat saat masih dalam situasi konflik antara kubu Romahurmuziy dengan Suryadarma Ali. Majelis partai memutuskan bahwa muktamar PPP hanya dapat digelar apabila kedua kubu sudah islah, namun apabila kedua kubu tidak bisa islah, penyelenggaraan muktamar akan diambil alih oleh majelis partai. Konflik antara kubu Suryadharma dan Romahurmuziy akan diselesaikan di 
mahkamah partai (Wijaya, 2020). Kubu Suryadharma Ali juga tak tinggal diam terhadap muktamar yang diadakan oleh Romahurmuziy dan menggelar Muktamar pada tanggal 30 oktober 2014 di Jakarta (Setyadi, 2020). Hasil Muktamar tersebut adalah menetapkan Djan Farid sebagai Ketua Umum PPP secara aklamasi, menerima laporan pertanggungjawaban pengurus DPP periode 2011-2015, mengamanatkan sikap PPP yang tetap pada Koalisi Merah Putih, memberi sanksi hukum kepada Romahurmuziy, Emron Pangkapi, dan Suharso Manoarfa (Tempo.co, 2014).

Kubu Romi mengklaim bahwa Muktamar di Surabaya sah, karena berdasarkan amanat Musyawarah Kerja Nasional III PPP yang digelar pada 23-24 April di Bogor agar DPP untuk menyelenggarakan Muktamar VIII selambat-lambatnya sebulan setelah pelaksanaan Pemilu Presiden. Muktamar tersebut juga dihadiri oleh oleh 26 dari 33 DPW PPP se Indonesia (Wardi, 2014). Pada 18 Oktober 2014, DPP PPP kubu M Romahurmuziy melaporkan hasil muktamar VIII yang digelar di Surabaya kepada Joko Widodo. Muktamar tersebut berisi tujuh poin sikap PPP (Faqih, 2014).

\subsection{Dampak konflik Internal DPP PPP}

Ada beberapa dampak konflik PPP bagi diantaranya sebagai berikut, Pertama, Dualisme Kepengurusan di daerah baik DPW maupun DPC, Kedua, Perebutan kantor DPP oleh Kubu Romahurmuzy dan Kubu Djan Farid. Pada tanggal 16 Juli 2017, Humprey Djemat Wakil Ketua Umum DPP PPP Kubu Djan Farid menuding penyerangan yang dilakukan oleh 80 massa ke kantor pusat PPP didalangi oleh Kubu Romahurmuzy. Namun, Kubu Romahurmuzy membantah dan mengancam akan melaporkan balik DPP PPP Kubu Djan
Farid ke kepolisian karena pendudukan mereka di Kantor Pusat DPP PPP tidak sah sejak adanya Putusan Peninjauan Kembali MA Nomor.79/2017 (Friana, 2017), Ketiga, Perebutan Kantor Sekertariat antara pihak-pihak yang pro kubu Romahurmuzy dan pro kubu Djan Farid.

Hingga Pemilu 2019, konflik internal PPP masih terus berlangsung terutama menjelang Pemilu 2019, karena perbedaan arah dukungan antara kubu Romahurmuzy dan Kubu Humprey Djemat. Politik belah bambu yang dilakukan oleh Rezim Jokowi terhadap PPP, semakin memperkeruh persoalan internal PPP, yang mestinya bisa diselesaikan pada ranah internal PPP sendiri. Politik belah bambu bukan saja mengakibatkan semakin tingginya ketidakpercayaan masyarakat pada PPP, namun juga merusak Islam politik pada panggung politik Indonesia. Terdapat indikator campur tangan pemerintah dalam kasus internal PPP, Pertama, pengangkatan Menteri Agama dari kubu PPP Romahurmuzy yaitu Lukman Hakim Syarifuddin, dengan harapan bahwa PPP diparlemen dapat mendukung pemerintahan Jokowi. Kubu Romahurmuzy kemudian menolak nama-nama komisi dan alat kelengkapan dewan yang diajukan oleh kubu Surya Dharma Ali, Kedua, Presiden Jokowi menggunakan kekuasaan kabinetnya, yaitu melalui Menkumham mengeluarkan surat yang menetapkan kubu Romahurmuzy adalah kubu yang legal dalam kepengurusan PPP.

Menurut Fisher penyebab konflik terdiri atas beberapa hal, Pertama, terjadinya polarisasi, ketidakpercayaan dan permusuhan antar kelompok yang berbeda dalam satu komunitas, Kedua, disebabkan posisi yang diadopsi kelompok bertentangan semata, Ketiga, 
kebutuhan manusia yang tidak tercukupi (fisik, psikologis dan sosial), Keempat, identitas yang terancam, Kelima, miskomunikasi antar budaya karena gaya yang berbeda, Kelima, transformasi konflik disebabkan karena ketidaksetaraan dan ketidakadilan. Dari beberapa faktor penyebab konflik yang disebutkan oleh Fisher, Dkk yang paling sesuai adalah sebagai berikut, Pertama, terjadinya polarisasi, ketidakpercayaan dan permusuhan antar kelompok yang berbeda dalam satu komunitas dan Kedua, disebabkan posisi yang diadopsi kelompok bertentangan semata.

Penelitian ini berusaha memperluas Teori Faktor Penyebab Konflik yang dikemukakan oleh Fisher dengan menambahkan sebuah poin bahwa terdapat faktor eksternal yang berasal dari luar kelompok yang berkonflik dibalik konflik yang terjadi di Partai Persatuan Pembangunan sehingga konflik tersebut, tidak mampu terselesaikan hingga saat ini yaitu faktor campur tangan pemerintah, misalkan keluarnya SK Kemenkumham yang mengesahkan salah satu pihak dan tidak mempertimbangkan kekecewaan pada pihak lain (Academic Gap). Sedangkan Empirical Gap seharusnya konflik PPP mampu diselesaikan oleh pihak pengadilan, namun nyatanya konflik PPP terus berlanjut hingga kini. Meskipun telah terbit Putusan Mahkamah Agung dengan mengesahkan Kubu Romahurmuzy, namun dualisme DPP Pusat masih terus berlangsung dengan ditunjukkannya arah kebijakan partai yang berlawan. Masing-masing pihak berusaha menunjukkan dominasinya terhadap partai dengan memberikan pernyataan-pertanyaan politik yang dapat menyebabkan terpecahnya suara partai arus bawah dan kebingungan konstituen.

\subsection{Resolusi Konflik PPP}

Proses Resolusi Konflik sebenarnya telah terjadi semenjak adanya Mukernas II yang di gelar di Bogor pada 24 April 2014 dengan adanya mediasi dan campur tangan pihak ketiga yaitu Mahkamah Partai Kyai Maemon Zubair. Resolusi konflik ini menurut Wahyudi merupakan Model Stimulasi Konflik adalah dengan mendorong konflik yang sedang terjadi dan membahasnya secara bersama-sama, secara sengaja dan direncanakan agar menemukan solusi yang lebih baik. Suryadharma Ali sempat meminta maaf dan mengakui kesalahannya. kedua kubu yakni kubu Suryadharma dan kubu Romahurmuzy akhirnya menyepakati islah. Namun, Pada tanggal 2 Mei 2014, Suryadharma Ali menyodorkan draft persetujuan dukungan untuk Capres Partai Gerindra pada rapat di Hotel JS Luwansa. Hal tersebut dinilai melanggar kesepakatan islah yang dipimipin oleh $\mathrm{KH}$ Maemun Zubair selaku Ketua Majelis Syariah DPP PPP pada tanggal 23 April 2014, dimana semua pihak yang terlibat perseteruan kembali ke posisi nol (Irfan, 2014).

Dualisme PPP memasuki babak baru semenjak tanggal 31 Oktober 2014, Menteri Hukum dan Hak Asasi Manusia Yasonna Laoly mengesahkan kubu Romahurmuzy (Sitompul, 2014). Menkum HAM menghimbau apabila ada pihak-pihak yang tidak terima untuk melapor ke PTUN. Kubu Djan Faridz bersama koalisi Merah Putih kemudian melaporkan hal tersebut ke PTUN Jakarta. Pemerintah juga mengangakat Menteri Agama dari Kubu Romahurmuzy yaitu Lukman Hakim Syarifuddin, dengan harapan bahwa PPP diparlemen dapat mendukung pemerintahan Jokowi. 
Pada tanggal 22 November 2016, Pengadilan Tata Usaha Negara (PTUN) Jakarta mengabulkan gugatan Djan Faridz yang meminta SK Menkum HAM soal pengesahan kubu Romahumuzy dibatalkan. Dengan keputusan PTUN Jakarta, Menkum HAM diwajibkan mencabut SK pengesahan kubu Romahurmuziy serta membayar biaya perkara (Kami, 2016). Hal tersebut diperkuat oleh keputusan Mahkamah Agung (MA) pada tanggal 20 Oktober 2015 yang memutuskan memperkuat putusan PTUN Jakarta memenangkan kubu Djan Faridz dalam sengketa kepengurusan PPP (Toriq, 2015). Namun, pada 17 Juni 2017, Mahkamah Agung (MA) mengabulkan gugatan Peninjauan Kembali (PK) yang diajukan kubu Romahurmuziy melalui putusan PK No.79 PK/Pdt.Sus-Parpol/2016. Dengan keputusan ini Menurut Romahurmuzy, seluruh dualisme kepemimpinan PPP berakhir dengan disahkan Romi sebagai Ketua Umum PPP hasil Muktamar Pondok Gede tahun 2016 (Purnamasari, 2017).

Hingga Pemilu 2019, konflik internal PPP masih terus berlangsung terutama menjelang Pemilu 2019, karena perbedaan arah dukungan antara kubu Romahurmuzy dan Kubu Humprey Djemat. Politik belah bambu yang dilakukan oleh Rezim Jokowi terhadap PPP, semakin memperkeruh persoalan internal PPP, yang mestinya bisa diselesaikan pada ranah internal PPP sendiri. Politik belah bambu bukan saja mengakibatkan semakin tingginya ketidakpercayaan masyarakat pada PPP, namun juga merusak Islam politik pada panggung politik Indonesia.

\section{Kesimpulan}

Partai Persatuan Pembangunan (PPP) merupakan fusi dari keempat Partai Islam yang ikut serta pada Pemilu
1971 untuk menyederhanakan sistem kepartaian menjelang Pemilu 1977. Menjelang Pemilu tahun 2014 partai ini dilanda konflik internal yang berlarutlarut hingga kini. Konflik internal yang seharusnya bisa diselesaikan oleh mekanisme internal partai gagal, hingga masuknya campur tangan pemerintah dengan terbitnya SK Menkumham dan dan pengangkatan Menteri Agama dari kubu PPP Romahurmuzy yaitu Lukman Hakim Syarifuddin. Pada tanggal 22 November 2016, Pengadilan Tata Usaha Negara (PTUN) Jakarta mengabulkan gugatan Djan Faridz yang meminta SK Menkum HAM soal pengesahan kubu Romahumuzy dibatalkan. Hal tersebut diperkuat oleh keputusan Mahkamah Agung (MA) pada tanggal 20 Oktober 2015 yang memutuskan memperkuat putusan PTUN Jakarta memenangkan kubu Djan Faridz dalam sengketa kepengurusan PPP. Namun, pada 17 Juni 2017, Mahkamah Agung (MA) mengabulkan gugatan Peninjauan Kembali (PK) yang diajukan kubu Romahurmuziy melalui putusan PK No.79 PK/Pdt.Sus-Parpol/2016.

\section{References}

Al-Hamdi, R. (2013). Partai Politik Islam Teori dan Praktik di Indonesia. Yogyakarta: Graha Ilmu .

Apter, D. (1985). Pengantar Analisa Politik. Jakarta: LP3ES.

Fatah, E. (1994). Manajemen Konflik dan Demokrasi. Jakarta: Jurnal Prisma

Gurr, T. (1980). Handbook of Political Conflic and Research. New York: The Free Press.

Haris, S. (1988). Menggugat Pemiliban Umum Orde Baru. Jakarta: Yayasan Obor Indonesia. 
Liwori, A. (2018). Prasangka, Konflik dan Komunikasi Antarbudaya Edisi Kedua. Jakarta : Kencana.

Poloma, M. (1994). Sosiologi Kontemporer. Jakarta: Rajawali Press.

bbc.com. (2014). "Konflik guncang PPP terkait

koalisi",https://www.bbc.com/i ndonesia/berita_indonesia/2014 /04/140419_konflik_ppp_koalisi

Faqih, M. (2014, 10 08). Malam Ini, PPP Kubu Romi Laporkan Hasil Muktamar ke Jokowi.https://www.republika.co. id/berita/nasional/politik/14/10 /18/ndn2a2-malam-ini-pppkubu-romi-laporkan-hasilmuktamar-ke-jokowi

Irfan, M. (2014). Awal Perseteruan 'Panas' PPP: https://www.medcom.id/nasion al/politik/zNPEYGEb-awalperseteruan-panas-ppp

Kami, I. M. (2016). PTUN Jakarta Menangkan Djan, Kepengurusan PPP Romi Batal: https:// news.detik.com/berita/d -3351469/ptun-jakartamenangkan-djan-kepengurusanppp-romi-batal

Friana, H. (2017). Kubu Djan Tuduh Romi Dalangi Penyerangan Kantor DPP PPP: https:/ / tirto.id/kubu-djantuduh-romi-dalangi-penyerangankantor-dpp-ppp-csMY

Pamungkas, N. (2019, 3 20). Detiknews. Dipetik 12 07, 2020, dari https://news.detik.com/kolom/ d-4475715/kasus-romahurmuziydan-pertaruhan-baru-ppp

Purnamasari, N. (2017). Detik.com. Dipetik 12 10, 2020, dari Romi Menang Gugatan di MA, Ini
Respons PPP Kubu Djan: https://news.detik.com/berita/d -3533705/romi-menang-gugatandi-ma-ini-respons-ppp-kubu-djan Puspita, W. (2018). Manajemen Konflik (Suatu Pendekatan Psikologi, Komunikasi dan Pendidikan). Yogyakarta: Penerbit Deepublish.

Rauf, M. (2000). Konsensus dan Konflik Politik. Jakarta: DIKTI.

Setyadi, A. (2020). SDA Gelar Muktamar, Anulir Romy sebagai Ketum: https://www.google.com/amp/s /nasional.okezone.com/amp/20 14/10/19/337/1054064/sdagelar-muktamar-anulir-romysebagai-ketum

Sitompul, J. M. (2014). Merdeka.com. Dipetik 12 10, 2020, dari Langkah SDA dan KMP usai Menkum HAM sahkan kubu Romi: https://www.merdeka.com/polit ik/langkah-sda-dan-kmp-usaimenkum-ham-sahkan-kuburomi.html

Surbakti, R. (2010). Memahami Ilmu Politik. Jakarta: Gramedia Widia Sarana.

Susan, N. (2017). Pengantar Sosiologi Konflik. Jakarta: Kencana Prenada Mediagroup.

Tempo.co. (2014, 11 01). Muktamar PPP Kubu SDA Sempat Ricuh. Dipetik 11 10, 2020, dari Tempo: https://nasional.tempo.co/read/ 618748/muktamar-ppp-kubusda-sempat-ricuh $/$ full\&view $={ }_{\mathrm{ok}}$

Toriq, A. (2015, 10 20). Detik.com. Dipetik 12 10, 2020, dari MA Menangkan Kubu Djan, ini 5 Pernyataan Sikap Kubu Romi: https:// news.detik.com/berita/d -3048953/ma-menangkan-kubu- 


\section{djan-ini-5-pernyataan-sikap- \\ kubu-romi}

Wardi, R. (2014, 10 14). Kubu Romy Klaim Muktamar di Surabaya Sah. Dipetik 12 09, 2020, dari Berita Satu : beritasatu.com/beritasatu/nasion al/217203/kubu-romy-klaimmuktamar-di-surabaya-sah

Wijaya, M. A. (2020, 10 07). Republika. Dipetik 12 08, 2020, dari Mbah Moen tak Akui Hasil Muktamar Surabaya Kubu Romy: https://www.republika.co.id/berit a/nasional/politik/14/10/17/ndk ukt-mbah-moen-tidak-akui-hasilmuktamar-surabaya-kubu-romy 